\title{
Enzyme profiling of lignocellulolytic fungi
}

\author{
D. K. ACHARYA ${ }^{1 *}$, S. B. CHABHADIYA ${ }^{1}$, A. J. SHAH ${ }^{1}$, P. SHILPKAR ${ }^{1}$, P. B. \\ ACHARYA $^{1}$ and H. A. MODI $^{2}$ \\ ${ }^{1}$ Biogas Research Centre and Post Graduate Department of Microbiology, Gujarat Vidyapeeth, Sadra 382 \\ 320, Gandhinagar, Gujarat, India. \\ ${ }^{2}$ Department of Life Science, Gujarat University, Ahmedabad 382 314, Gujarat, India. \\ * Corresponding author, E-mail: dkacharya07@yahoo.com, Telephone and Fax: +91-79-23274274
}

\begin{abstract}
Lignocellulolytic fungi produce a variety of lignocellulolytic enzymes which are responsible for the biodegradation of lignocellulosic agro-wastes in nature. These enzymes are also useful for biofuel production, bio-bleaching, bio-pulping etc. We have isolated ecodiversely different seventeen fungi from ecorich soils of Gandhinagar region, Gujarat, India. The objective of this work was to study enzyme production profile by lignocellulolytic fungi, using wheat straw as a model agro-waste by solid state fermentation. Most of these lignocellulolytic fungi have been found to express enzyme activities like filter paper activity (FPase), endoglucanase, exocellulase, $\beta$-glucosidase, xylanase, glucoamylase, manganese peroxidase $(\mathrm{MnP})$ and protease. Among these, A. niger, A. oryzae and Sporotrichum sp. produce endocellulase and xylanase in significant amount. A. niger and Sporotrichum sp. gave $52.47 \mathrm{U} / \mathrm{g}$ and $69.441 \mathrm{U} / \mathrm{g}$ endocellulase activity, and $48.107 \mathrm{U} / \mathrm{g}$ and $112.649 \mathrm{U} / \mathrm{g}$ xylanase activity, respectively.

(C) 2010 International Formulae Group. All rights reserved.
\end{abstract}

Key words- Aspergillus niger, Aspergillus oryzae, Sporotrichum sp., fungal isolation, solid state fermentation, wheat straw

\section{INTRODUCTION}

Agricultural waste contains a high proportion of lignocellulose, which have potentials for bioconversion. Agricultural and agro-industrial waste increased as a result of industrialization, becoming a problem regarding space for disposal and environmental pollution (da Silva et al., 2005). A lignocellulosic plant material contains higher cellulose (23-53\%) with lesser but significant amounts of hemicellulose (20$35 \%)$ and lignin (10-25\%) and other extractable compounds (Knauf and Moniruzzaman, 2004). Cellulose and hemicellulose represent more than $50 \%$ of the dry weight of agricultural residues. These polymers can be converted into fermentable sugars by enzymatic hydrolysis, so it can be used as a plentiful and cheap source of liquid fuels, food products or other chemicals of interest (Romero et al., 1999; Kang et al., 2004).

The hydrolytic action of cellulases and hemicellulases is of fundamental importance to obtain fermentable sugars from lignocellulosic biomass (Leite et al., 2007). The enzymatic hydrolysis of cellulose into glucose involves the synergistic action of at least three different enzymes: endocellulase (EC 3.2.1.4), exocellulase (EC 3.2.1.91) and 
$\beta$-1, 4-glucosidase (EC 3.2.1.21) (Acharya et al., 2008). The enzymatic hydrolysis of xylan requires mainly two enzymes viz. $\beta-1$, 4endoxylanase (EC 3.2.1.8) and $\beta$-xylosidase (EC 3.2.1.37) (Leite et al., 2007). However, for complete hydrolysis of hemicellulose, $\alpha$-Larabinofuranosidase (EC 3.2.1.55), endomannanases $\quad(\mathrm{EC} \quad 3.2 .1 .78), \quad \beta$ mannosidases (EC 3.2.1.25) and $\alpha$ galactosidases (EC 3.2.1.22) are also required (Jorgensen et al., 2005). The main extracellular enzymes participating in lignin degradation are lignin peroxidase (EC 1.11.1.14), manganese peroxidase (EC 1.11.1.13) and laccase (EC 1.10.3.2) (Hatakka, 2001).

The enzymatic hydrolysis of lignocellulose represents a special case of enzymology, since the substrate is solid and hydrolysis occurs in the solid phase. Production of enzymes by Solid State Fermentation (SSF) offers several advantages over submerged system, simply because of its low operational and production cost. At the same time, SSF uses inexpensive agro-waste materials as substrates. The use of agro-wastes not only helps to overcome problem of solid waste management but also allows the development of biotechnological processes from cheap natural resources. Enzymes remain most frequently reported metabolites produced via SSF, some of which include cellulases, xylanases, lipases, phytase, protease, lignin degrading enzymes and pectinases (Pang et al., 2006).

Wheat straw is an abundant byproduct from wheat production. The average yield of wheat straw is 1.3-1.4 lb per lb wheat grain (Montane et al., 1998; Saha and Cotta, 2006). Wheat straw contains 35$45 \%$ cellulose, $20-30 \%$ hemicellulose and 8$15 \%$ lignin and can also serve as a low cost attractive feedstock (Saha and Cotta, 2006). In recent years using fungi as biotechnological sources of industrially relevant enzymes has stimulated interest in the exploration of extracellular enzymatic activity. Filamentous fungi are attracting greater attention as potential sources of plant cell wall hydrolyzing enzymes, because they secrete high levels of the enzymes into culture medium (Berry and Paterson, 1990).

In our search for fungi capable of efficiently degrading lignocelluloses, some lignocellulolytic fungi were isolated from Gandhinagar region, Gujarat, India. The present study focused on profiling of enzyme production from lignocellulolytic fungi.

\section{MATERIALS AND METHODS Fungal strains and culture conditions}

A total of 13 strains were used in present experiment. These strains were soil inhabitant and isolated from soils of Sadra, Rajpur and Alua hills regions of Gandhinagar $\left(23.22^{\circ} \mathrm{N}\right.$ and $\left.72.68^{\circ} \mathrm{E}\right)$. Soil samples were collected aseptically in UV sterilized plastic bags using sterile specula from top 9 inch layer of soil. In the laboratory, $1 \mathrm{~g}$ soil was transferred aseptically into $9 \mathrm{~mL}$ sterile distilled water and mixed thoroughly. From this, $0.1 \mathrm{~mL}$ was spread over Potato Dextrose Agar (PDA) in Petri plates and the plates were incubated at $28{ }^{\circ} \mathrm{C}$ for 5-7 days. After colonial growth pure culture were obtained by repeatedly transferring on PDA plates. Pure cultures were stored on PDA slants at $4{ }^{\circ} \mathrm{C}$. Phanerochaete chrysosporium was used as a model strain for comparative study and was obtained from National Chemical Laboratory, Pune, India.

\section{Media preparation and enzyme production \\ Enzyme production was carried out using untreated wheat straw as carbon source by solid state fermentation technique. The moisture content was maintained between 60- $70 \%$ using salt medium (Ekperigin, 2007), which contained $0.01 \% \quad \mathrm{MgSO}_{4}, \quad 0.1 \%$ $\left(\mathrm{NH}_{4}\right)_{2} \mathrm{SO}_{4}, 0.2 \% \mathrm{KH}_{2} \mathrm{PO}_{4}, 0.7 \% \mathrm{~K}_{2} \mathrm{HPO}_{4}$ and $0.05 \%$ Na-citrate. $\mathrm{pH}$ of media adjusted to $5.0 \pm 0.2$. Three gram wheat straw was placed in $250 \mathrm{ml}$ conical flask and moistened with 6 $\mathrm{ml}$ salt medium in duplication. It was then sterilized by autoclaving at $121{ }^{\circ} \mathrm{C}$ for $15 \mathrm{~min}$ followed by cooling and inoculation with 10 discs of $8.0 \mathrm{~mm}$ diameter of organism from}


PDA culture plates using sterile cork borer. Flasks were incubated at $28 \pm 5{ }^{\circ} \mathrm{C}$ for 8 days.

\section{Extraction of extracellular enzymes}

The fermented substrate was extracted with $50 \mathrm{ml}$ citrate buffer ( $\mathrm{pH} 4.8 ; 50 \mathrm{mM}$ ) by shaking the mixture at $180 \mathrm{rpm}$ for $30 \mathrm{~min}$ at $28 \pm 2{ }^{\circ} \mathrm{C}$ and filtered through Whatman No. 2 filter paper. The filtrate was used for profiling of various enzymes.

\section{Measurement of enzyme activities}

All activity tests were conducted in a $50 \mathrm{mM}$ citrate buffer having $\mathrm{pH}$ 4.8. The total cellulase activity was measured as filterpaperase (FPase) against Whatmann No.1 filter paper (Ghose, 1986). The total endoglucanase activity was determined against carboxymethylcellulose (CMC) (Ghose, 1986). The exocellulase activity was determined against cotton. The $\beta$-glucosidase activity was determined against salicilin (Chahal, 1985). The Endo- $\beta-1,4$-xylanase activity was determined against birchwood xylan (Bailey et al., 1992) and glucoamylase activity was determined against starch (Ghose, 1986). The reducing sugar produced was determined by the DNS method (Miller, 1959). One international unit (U) was defined as the enzymatic activity needed for the release of $1 \mu \mathrm{mol}$ of glucose equivalents per unit volume and minute of reaction. The protease enzyme was assayed following casein substrate method using L-tyrosine as standard (Anson, 1938). The manganese peroxidase (MnP) activity was determined spectrometrically against phenol (Kuwahara et al., 1984). One international unit (U) was defined as the amount of enzyme that oxidized $1 \mu \mathrm{mol}$ of dimethoxyphenol per minute.

\section{Statistical analysis}

Results were analyzed for standard deviation following the method suggested by Rangaswami (1995).

\section{RESULTS}

All the isolates were identified at Agharkar Research Institute, Pune, India. All isolates exhibited endoglucanase, exocellulase, $\beta$-glucosidase and filter paper activity (FPase) activities (Table 1). The contents of endoglucanase, $\beta$-glucosidase, exocellulase and FPase activities were recorded as 52.47, 6.172, 0.656 and $9.259 \mathrm{U} / \mathrm{g}$ in A. niger; 69.441, 16.974, 0.712 and 6.794 $\mathrm{U} / \mathrm{g}$ in Sporotrichum sp. and 2.16, 6.172, 0.463 and $6.172 \mathrm{U} / \mathrm{g}$ in $A$. oryzae, respectively. Compared to $P$. chrysosporium, A. niger and Sporotrichum sp. gave 2.8 and 2.1 fold high endoglucanase respectively, and same FPase activity was observed with $A$. niger, while $A$. oryzae and Sporotrichum sp. gave 1.5 and 1.4 fold lesser FPase activity. These three organisms gave lesser $\beta$ glucosidase activity than $P$. chrysosporium. As shown in Table 1, FPase activity was successfully detected for all species.

Maximum endoxylanase activity (112.649 U/g) was given by Sporotrichum sp., while $A$. niger and A. oryzae gave 48.107 and $14.802 \mathrm{U} / \mathrm{g}$ respectively (Table 1 ). While $P$. chrysosporium gave 3.4 and 1.5 fold lesser endoxylanase activity than Sporotrichum $s p$ and $A$. niger and 2.3 fold higher than $A$. oryzae.

Highest glucoamylase activity (52.466 U/g) was observed in Sporotrichum $s p$. whereas 5.090 and $5.401 \mathrm{U} / \mathrm{g}$ glucoamylase activity was determined in $A$. niger and $A$. oryzae respectively. $P$. chrysosporium gave $4.63 \mathrm{U} / \mathrm{g}$ glucoamylase activity (Table 1), which was approximately 11, 1.2 and 1.1 fold lesser than Sporotrichum sp., A. oryzae and A. niger, respectively.

$P$. chrysosporium gave $3.817 \mathrm{U} / \mathrm{l}$ $\mathrm{MnP}$ activity, while $2.312 \mathrm{U} / \mathrm{l}, 0.914$ and $0.433 \mathrm{U} / 1 \mathrm{MnP}$ activity were observed with $A$. oryzae, A. niger and Sporotrichum sp., respectively (Table 1). $P$. chrysosporium gave $2.39 \mathrm{U} / \mathrm{ml}$ while $A$. oryzae, A. niger and Sporotrichum sp. gave 2.450, 3.435 and 0.998 $\mathrm{U} / \mathrm{ml}$, protease activity respectively (Table 1 ). It means enzymes produced bySporotrichum $s p$. were more stable than those from $P$. chrysosporium, A. oryzae and A. niger. Phytase activity was also analyzed but unfortunately none of the organisms produced phytase enzyme.

\section{DISCUSSION}

Cellulase activity decreased with time which may be due to the accumulative 
Table 1: Enzymatic activity of isolated lignocellulolytic fungal strains.

\begin{tabular}{|c|c|c|c|c|c|c|c|c|}
\hline Name of Strain & $\begin{array}{l}\boldsymbol{\beta} \text {-Glucosidase } \\
(\mathrm{U} / \mathrm{g}) \\
\end{array}$ & $\begin{array}{l}\text { Endocellulase } \\
(\mathrm{U} / \mathrm{g}) \\
\end{array}$ & $\begin{array}{l}\text { Exocellulase } \\
(\mathrm{U} / \mathrm{g}) \\
\end{array}$ & $\begin{array}{l}\text { FPase } \\
(\mathrm{U} / \mathrm{g}) \\
\end{array}$ & $\begin{array}{l}\text { Xylanase } \\
(\mathrm{U} / \mathrm{g}) \\
\end{array}$ & $\begin{array}{l}\text { Glucoamylase } \\
(\mathrm{U} / \mathrm{g}) \\
\end{array}$ & $\begin{array}{l}\text { Protease } \\
(\mathrm{U} / \mathrm{mL}) \\
\end{array}$ & $\begin{array}{l}\text { MnP } \\
(\mathrm{U} / \mathrm{L}) \\
\end{array}$ \\
\hline P.chrysosporium & $22.34 \pm 0.859$ & $24.69 \pm 0.988$ & $1.273 \pm 0.058$ & $9.259 \pm 0.369$ & $33.305 \pm 1.259$ & $4.63 \pm 0.206$ & $1.243 \pm 0.050$ & $3.817 \pm 0.191$ \\
\hline Rhizopus sp. & $6.172 \pm 0.306$ & $15.43 \pm 0.770$ & $1.968 \pm 0.078$ & $4.629 \pm 0.196$ & $37.005 \pm 1.428$ & $5.401 \pm 0.262$ & $0.759 \pm 0.035$ & $3.28 \pm 0.160$ \\
\hline Aspergills oryzae & $6.172 \pm 0291$ & $2.16 \pm 0.101$ & $0.463 \pm 0.023$ & $6.172 \pm 0.227$ & $14.802 \pm 0.681$ & $5.401 \pm 0.158$ & $1.519 \pm 0.161$ & $2.312 \pm 0.098$ \\
\hline Aspergills niger & $9.259 \pm 0.394$ & $15.43 \pm 0.569$ & $0.424 \pm 0.020$ & $4.629 \pm 0.126$ & $11.102 \pm 0.432$ & $0.772 \pm 0.111$ & $0.912 \pm 0.035$ & $2.849 \pm 0.143$ \\
\hline Aspergills niger & $6.172 \pm 0.159$ & $52.47 \pm 1.868$ & $0.656 \pm 0.087$ & $9.259 \pm 0.354$ & $48.107 \pm 1.933$ & $5.09 \pm 0.159$ & $2.762 \pm 0.123$ & $0.914 \pm 0.208$ \\
\hline Aspergills oryzae & $6.172 \pm 0.222$ & $2.16 \pm 0.089$ & $0.694 \pm 0.077$ & $3.086 \pm 0.126$ & $25.903 \pm 1.010$ & $7.87 \pm 0.274$ & $1.105 \pm 0.105$ & $3.71 \pm 0.119$ \\
\hline Sporotrichm sp. & $3.086 \pm 0.099$ & $18.52 \pm 0.889$ & $1.543 \pm 0.129$ & $7.716 \pm 0.399$ & $9.399 \pm 0.388$ & $4.786 \pm 0.191$ & $0.552 \pm 0.029$ & $0.376 \pm 0.036$ \\
\hline Aspergills niger & $9.259 \pm 0.258$ & $64.811 \pm 2.380$ & $0.831 \pm 0.092$ & $3.858 \pm 0.202$ & $84.87 \pm 3.284$ & $21.603 \pm 1.081$ & $0.652 \pm 0.056$ & $0.108 \pm 0.031$ \\
\hline Aspergills oryzae & $9.259 \pm 0.394$ & $67.898 \pm 3.241$ & $0.712 \pm 0.099$ & $6.172 \pm 0.280$ & $61.72 \pm 2.019$ & $26.233 \pm 1.180$ & $1.441 \pm 0.222$ & $0.323 \pm 0.051$ \\
\hline Sporotrichum sp. & $16.974 \pm 0.662$ & $69.441 \pm 3.646$ & $0.712 \pm 0.087$ & $6.794 \pm 0.309$ & $112.649 \pm 4.506$ & $52.466 \pm 1.281$ & $0.998 \pm 0.086$ & $0.433 \pm 0.036$ \\
\hline Aspergills fumigates & $0.463 \pm 0.023$ & $66.354 \pm 2.598$ & $0.949 \pm 0.099$ & $9.259 \pm 0.351$ & $13.117 \pm 0.487$ & $15.431 \pm 0.544$ & $1.211 \pm 0.154$ & $0.269 \pm 0.050$ \\
\hline Neurospora crass & $12.345 \pm 0.581$ & $6.481 \pm 0.189$ & $0.823 \pm 0.081$ & $6.481 \pm 0.288$ & $85.111 \pm 3.298$ & $17.623 \pm 1.011$ & $0.266 \pm 0.041$ & $3.748 \pm 0.132$ \\
\hline Aspergills nidulus & $19.521 \pm 0.881$ & $10.108 \pm 0.388$ & $1.039 \pm 0.108$ & $7.963 \pm 0.308$ & $111.015 \pm 3.881$ & $19.536 \pm 0.969$ & $1.459 \pm 0.321$ & $2.498 \pm 0.143$ \\
\hline Aspergillus sp. & $11.265 \pm 0.446$ & $14.737 \pm 0.589$ & $0.795 \pm 0.094$ & $5.509 \pm 0.282$ & $74.01 \pm 2.556$ & $7.129 \pm 0.334$ & $0.286 \pm 0.039$ & $14.991 \pm 0.443$ \\
\hline
\end{tabular}


effect of cellulobiose, which is dimmer of glucose and known to inhibit both endoglucanase and glucosidase (Howell, 1978). The time of the highest cellulase activity depends upon substrate and fungus used (Ojumu et al., 2003). As discussed by Hatakka (1983), delignification produces aromatic water-soluble products which can also repress the cellulolytic action of the enzyme.

For total hydrolysis of lignocellulosic material, synergistically acting enzymes are needed. Xylan is the main carbohydrate found in hemicellulose. Xylanase belong to glycosyl hydrolase families 10 and 11 (Biely et al., 1997). High xylanase production in wheat straw could be attributed to its hemicellulosic nature and favorable degradability as well as the presence of some nutrients in the carbon source (Sonia et al., 2005). Angayarkanni et al. (2006) studied A. indicus and A. flavus which gave 145.044 and $140.810 \mathrm{IU} / \mathrm{ml}$ endoxylanase activity respectively. In lignocellulolytic waste there were traces of starch, on which amylase acted and produced glucose monomers. Glucoamylase consecutively hydrolyzes $\alpha-1,4$ glycosidic bonds from non-reducing ends of starch, resulting in the production of glucose (Pavezzi et al., 2008).

The multienzyme system involved in lignin degradation and mineralization is constituted of different ligninolytic enzymes combination, being the occurrence of $\mathrm{MnP}$ and laccase higher than LiP (Wesenberg et al., 2003). The role played by $\mathrm{MnP}$ in lignin degradation has been proposed as indirect by providing $\mathrm{H}_{2} \mathrm{O}_{2}$ for lignin peroxidase reactions (Kirk and Chang, 1980; Tien and Kirk, 1984; Kirk and Eriksson, 1981; Eriksson et al., 1990; Hossain and Anantharaman, 2006). The peroxidases used hydrogen peroxide generated by glyoxal oxidase, glucose oxidase, and cellobiose oxidase to promote the oxidation of lignin to free radicals that then underwent spontaneous reactions with oxygen or water, leading to depolyrmerization (Bennet et al., 2002).
Baldrian and Snajdr (2006) studied the production of lignolytic enzymes by litterdecomposing fungi in HNHC medium. They studied eight different fungal strains and $T$. versicolor gave higher $\mathrm{MnP}$ (33.2 U/l) than others at 17 th day while $P$. ostretus gave 1.9 $\mathrm{U} / 1$ at the 21st day. Bonnarme and Jeffries (1990) studied P. chrysosporium BKM, which gave $86 \mathrm{U} / 1$ at 8 th day and $P$. chrysosporium HHB6251 gave $29 \mathrm{U} / \mathrm{MnP}$ activities at 7 th day.

In addition to lignocellulolytic enzymes the protease activity was also measured because the presence of protease may affect the stability of xylanase during extraction and storage (Gessesse and Mamo, 1999). It was therefore considered essential that the protease titer of selected organisms should be as lower as possible

\section{Conclusion}

Isolated fungi exploring from Gandhinagar region, revealed that they can produce lignocellulolytic enzymes directly utilizing abundantly available lignocellulosic waste, wheat straw. Among 13 isolates $A$. niger, A. oryzae and Sporotrichum sp., were screened as potent lignocellulolytic fungi.

\section{ACKNOWLEDGEMENTS}

We are very thankful to Gujarat Vidyapeeth for providing financial support and laboratory facilities to conduct the present study.

\section{REFERENCES}

Acharya PB, Acharya DK, Modi HA. 2008. Optimization for cellulase production by Aspergillus niger using saw dust as substrate. African Journal of Biotechnology, 7(22): 4147-4152.

Angayarkanni J, Palaniswamy M, Pradeep BV, Swaminathan K. 2006. Biochemical substitution of fungal xylanases for prebleaching of hardwood Kraft pulp. African Journal of Biotechnology, 5(10): 921-929.

Anson ML. 1938. The estimation of pepsin, trypsin, papain and cathepsin with 
hemoglobin. Journal of General Physiology, 22: 79-89.

Bailey MJ, Biely P, Poutanen K. 1992. Interlaboratory testing of methods for assay of xylanase activity. Journal of Biotechnology, 23: 257-270.

Baldrian P, Snajdr J. 2006. Production of ligninolytic enzymes by litter decomposing fungi and their ability to decolorize synthetic dyes. Enzyme and Microbiological Technology, 39: 10231029.

Bennet JW, Wunch KG, Faison BD. 2002. Use of fungi in biodegradation. In Manual of Environmental Microbiology (2nd edn), Hurst CJ (ed). ASM Press: Washington, DC.

Berry DR, Paterson A. 1990. Enzymes in food industry. In Enzyme Chemistry, Impact and Applications (2nd edn), CJ Suckling (Ed); 306-351.

Biely P, Vrasanska M, Tenkanen M, Kluepfel D. 1997. Endo- $\beta$-xylanase families: differences in catalytic properties. Journal of Biotechnology, 57: 151-166.

Bonnarme P, Jeffries TW. 1990. Mn(1l) regulation of lignin peroxidases and manganese dependent peroxidases from lignin degrading white rot fungi. Applied and Environmental Microbiology, 56(1): 220-217.

Chahal DS. 1985. Solid-State Fermentation with Trichoderma reesei for cellulase production. Applied and Environmental Microbiology, 49(1): 205-210.

Da Silva R, Lago ES, Merheb CW, Macchione MM, Park YK, Gomes E. 2005. Production of xylanase and CMCase on solid state fermentation in different residues by Thermoascus aurantiacusmiehe. Brazilian Journal of Microbiology, 36: 235-241.

Ekperigin MM. 2007. Preliminary studies of cellulase production by Acinetobacter anitratus and Branhamella sp. African Journal of Biotechnology, 6(1): 028-033.

Eriksson KE, Blanchette RA, Ander P. 1990. Microbial and Enzymatic Degradation of
Wood and Wood Components. Springer Inc Ltd: New York, USA.

Gessesse A, Mamo G. 1999. High-level xylanases production by an alkaliphilic Bacillus sp using solid state fermentation. Enzyme and Microbial Technology, 25: 68-72.

Ghose TK. 1986. Measurement of cellulase activities. Pure and Applied Chemistry, 59: 257-268.

Hatakka AI. 2001. Biodegradation of lignin. In Biopolymers (vol. 1), Hofrichter M, Steinbüchel A (eds). Wiley-VCH: Weinheim, Germany.

Hatakka AI. 1983. Biological pretreatment of lignocellulose. Applied Microbiology and Biotechnology, 18: 350-357.

Hossain SKM, Anantharaman N. 2006. Activity enhancement of ligninolytic enzymes of Trametes versicolor with bagasse powder. African Journal of Biotechnology, 5(1): 189-194.

Howell JA. 1978. Enzymatic deactivation during cellulose hydrolysis. Biotechnology and Bioengineering, 20: 847-863.

Jorgensen H, Morkeberg A, Krogh KBR, Olsson L. 2005. Production of cellulases and hemicellulases by three Penicillium species: Effect of substrate and evaluation of cellulase adsorption by capillary electrophoresis. Enzyme and Microbial Technology, 36: 42-48.

Kang SW, Park YS, Lee JS, Hong SI, Kim SW. 2004. Production of cellulases and hemicellulases by Aspergillus niger KK2 from lignocellulosic biomass. Bioresource Technology, 91: 153-156.

Kirk TK, Chang HM. 1980. Biotechnology in Pulp and Paper Manufacture. Butterworth Hanimenam Publication: New York, USA.

Kirk TK, Eriksson KE. 1981. Lignin biodegradation with white-rot fungi. In Comprehensive Biotechnology (Vol. 4), Robinson CW, Howell JA (eds). Pergamon Press Ltd: Oxford.

Knauf M, Moniruzzaman M. 2004. Lignocellulosic biomass processing: A 
perspective. International Sugar Journal, 106 (1263): 147-150.

Kuwahara M, Glenn JK, Morgan MA, Gold MH. 1984. Separation and characterization of two extracellular $\mathrm{H}_{2} \mathrm{O}_{2}$-dependent oxidases from ligninolytic cultures of Phanerochaete chrysosporium. FEBS Letters, 169: 247250.

Leite RSR, Bocchini DA, Martins EDS, Silva D, Gomes E, da Silva R. 2007. Production of cellulolytic and hemicellulolytic enzymes from Aureobasidium pulluans on solid state fermentation. Applied Biochemistry and Biotechnology, 136-140: 281-288.

Miller GL. 1959. Use of dinitrosalicylic acid reagent for determination of reducing sugars. Analytical Chemistry, 31: 426428.

Montane D, Farriol X, Salvado J, Jollez P, Chomet E. 1998. Application of stream explosion to the fractionation and rapid vapor phase alkaline pulping of wheat straw. Biomass \& Bioenergy, 14: 261276.

Ojumu TV, Solomon BO, Betiku E, Layokun SK, Amigun B. 2003. Cellulase production by Aspergillus flavus Linn isolate SPR 101 fermented in sawdust, bagasse and corncob. African Journal of Biotechnology, 2(6): 150-152.

Pang PK, Darah I, Poppe L, Szakacs G, Ibrahim CO. 2006. Xylanase production by a local isolate, Trichoderma spp. FETL c3-2 via solid state fermentation using agricultural wastes as substrates. Malaysian Journal of Microbiology, 2(1): 7-14.

Pavezzi FC, Gomes E, Da Silva R. 2008. Production and characterization of glucoamylase from fungus Aspergillus awamori expressed in yeast Saccharomyces cerevisiae using different carbon sources. Brazilian Journal of Microbiology, 39: 108-114.

Rangaswami R. 1995. A Text Book of Agricultural Statistics. New Age International Pub. Ltd: New Delhi

Romero MD, Aguada J, Gonzales L, Ladero M. 1999. Cellulase production by Neurospora crassa on wheat straw. Enzyme and Microbial Technology, 25: 244-250.

Saha BC, Cotta MA. 2006. Ethanol production from alkaline peroxide pretreated enzymatically saccharified wheat straw. Biotechnology Progress, 22: 449-453

Sonia KG, Chadha BS, Saini HS. 2005. Sorghum straw for xylanase hyperproduction by Thermomyces lanuginosus (D2W3) under solid state fermentation. Bioresource Technology, 96(14): 15611569.

Tien M, Kirk TK. 1984. Lignin degrading enzyme from Phanerochate chrysosporium: purification, characterization and catalytic properties of a unique $\mathrm{H}_{2} \mathrm{O}_{2}$-requirung oxygenease. Proceedings of the National Academy of Sciences, 81: 2280-2284.

Wesenberg D, Kyriakides I, Agathos SN. 2003. White rot fungi and their enzymes for the treatment of industrial dye effluents. Biotechnology Advances, 22: 161-18. 